Article

\title{
Exergetic Analysis of a Natural Gas Combined-Cycle Power Plant with a Molten Carbonate Fuel Cell for Carbon Capture
}

\author{
Alberto Fichera ${ }^{1}$, Samiran Samanta ${ }^{2, *}$ and Rosaria Volpe ${ }^{1}$ (D) \\ 1 Department of Electrical, Electronics and Computer Engineering, University of Catania, \\ Viale Andrea Doria 25, 95125 Catania, Italy; alberto.fichera@dieei.unict.it (A.F.); rosaria.volpe@unict.it (R.V.) \\ 2 School of Mechanical Engineering, Kalinga Institute of Industrial Technology, Deemed to be University, \\ Bhubaneswar 751024, Odisha, India \\ * Correspondence: samirankgec@gmail.com or samiran.samantafme@kiit.ac.in
}

check for updates

Citation: Fichera, A.; Samanta, S.; Volpe, R. Exergetic Analysis of a Natural Gas Combined-Cycle Power Plant with a Molten Carbonate Fuel Cell for Carbon Capture.

Sustainability 2022, 14, 533.

https://doi.org/10.3390/su14010533

Academic Editor: Dino Musmarra

Received: 9 November 2021

Accepted: 28 December 2021

Published: 4 January 2022

Publisher's Note: MDPI stays neutral with regard to jurisdictional claims in published maps and institutional affiliations.

Copyright: (c) 2022 by the authors. Licensee MDPI, Basel, Switzerland. This article is an open access article distributed under the terms and conditions of the Creative Commons Attribution (CC BY) license (https:// creativecommons.org/licenses/by/ $4.0 /)$.

\begin{abstract}
This study aims to propose the repowering of an existing Italian natural-gas fired combined cycle power plant through the integration of Molten Carbonate Fuel Cells (MCFC) downstream of the gas turbine for $\mathrm{CO}_{2}$ capture and to pursuit an exergetic analysis of the two schemes. The flue gases of the turbine are used to feed the cathode of the MCFC, where $\mathrm{CO}_{2}$ is captured and transported to the anode while generating electric power. The retrofitted plant produces 787.454 MW, in particular, 435.29 MW from the gas turbine, 248.9 MW from the steam cycle, and 135.283 MW from the MCFC. Around $42.4 \%$ of the exergy destruction has been obtained, the majority belonging to the combustion chamber and, in minor percentages, to the gas turbine and the MCFC. The overall net plant efficiency and net exergy efficiency are estimated to be around 55.34 and $53.34 \%$, respectively. Finally, the specific $\mathrm{CO}_{2}$ emission is around $66.67 \mathrm{~kg} / \mathrm{MWh}$, with around 2 million tons of carbon dioxide sequestrated.
\end{abstract}

Keywords: molten carbonate fuel cell (MCFC); power plant; carbon capture; repowering; combined cycle

\section{Introduction}

In recent years, the need to address the environmental issues associated with the exploitation of fossil sources in power plants has been largely debated. The urgent commitment to reducing carbon emissions, however, collides with the increase in the global energy demand and with the expected increase in the global population, especially in urban areas [1]. Despite the optimistic growth of renewable energy-based production systems [2], fossil sources are projected to maintain their role of satisfying the electricity demand, especially in the short term [3]. One way to couple the needs for both reducing emissions and satisfying the global energy demand can be represented by carbon capture and storage technologies integrated into existing power plants, capable of reducing the release of carbon dioxide into the atmosphere. Carbon capture can be achieved by integrating either oxy-fuel or precombustion or post-combustion capture technologies. On one hand, oxy-fuel and precombustion allow for higher energy efficiencies of the power plants, but, on the other side, post-combustion technologies can be more easily integrated into existing plants [4]. With a view of enabling the repowering of existing plants, and thus focusing on post-combustion solutions, Molten Carbonate Fuel Cell (MCFC) may be considered a suitable candidate technology to capture carbon dioxide from flue gases deriving from the gas turbine of the power plant [5]. Indeed, MCFC combines the advantage of capturing $\mathrm{CO}_{2}$ emissions while producing useful power. Moreover, as demonstrated by Gatti et al. [6], the integration of MCFC in natural gas combined-cycle power plants also permits a target of lower costs of $\mathrm{CO}_{2}$ captured if compared with the monoethanolamine (MEA) and aqueous piperazine (PZ) absorption, and is more attractive in terms of energy penalty. A similar analysis, but including economic analysis and carrying out a bottom-up approach for the 
identification of plant costs, has been conducted by Campanari et al. [7]. Haghighat Mamaghani et al. [8] used a multi-objective model to assess how some operating parameters, such as the inlet temperature of the turbine, the isentropic efficiency of the turbine and the compressor or the fuel utilization factor, may impact the overall exergy efficiency of the modified MCFC-gas turbine plant. An optimization model is also proposed by Mahmoudi and Ghavimi for the MCFC integrated with two bottoming cycles for the evaluation of the net efficiency and overall cost for the operating temperature and current density of the fuel cell [9]. A significant part of the literature dealt with the integration of MCFC with reference to concentrating solar systems [10], biomass-based plants [11], or coal power plants, as in $[12,13]$. Li et al. examined the carbon footprint of a polygeneration process for coal-based chemical power and MCFC [14]. Other studies compared the performances of MCFC for both coal-based and natural gas power plants [15]. Overall, the literature demonstrated that MCFC integrated to natural gas combined cycles and, generally, a fuel cell-based solution, represents one of the most competitive carbon capture technologies [16]. An application for refrigeration needs has been presented in the work of Mehrpooya et al. [17], then enlarged by discussing the economic convenience of the investment [18]. Campanari et al. [19] positioned the MCFC between the gas turbine and the heat recovery steam generator (HRSG). Results have been derived from industrial experiences and demonstrated the potential for removing $\mathrm{CO}_{2}$ and also for increasing the overall power output. In their subsequent work, authors conducted a sensitivity analysis to deepen how different operating parameters (the current density, carbon, and fuel utilization factor, steam-to-carbon factor) may impact the performances of the MCFC [20]. Carapellucci et al. [21] compared the traditional recirculation of exhaust gases at the compressor inlet with the MCFC recirculation of anode gases at the cathode inlet, demonstrating the increase in the plant capacity of the plant of around $39 \%$ and a reduction of carbon emissions, for equal efficiency targets. From the technological viewpoint, and especially considering different layouts of the cell system and a cryogenic section, Manzolini et al. [22] proved how external reforming could ensure simplified construction stages of the stack. The performances of MCFC in terms of $\mathrm{CO}_{2}$ capture rate and electrical power generation have been also tackled by Carapellucci et al. [23] and by Barelli et al. [24], the latter including a capital investment analysis.

As demonstrated by the literature review conducted so far, there is significant interest in integrating MCFC in existing power plants with application to natural gas combined cycles. Although significant research papers are focusing on this topic, the discussion on MCFC performances for natural gas combine cycle power plants remains open and is suitable for further evaluation, especially if considering existing power plants configurations. As highlighted, the presented literature debated the technical performances of the MCFC, the most impactful operating parameters, or the cost-effectiveness of the implementation. The research presented here aims at contributing to the existing knowledge of MCFC by proposing thermodynamic analysis based on the exergy estimation. To the scope, an existing natural gas-fired combined-cycle power plant of $830 \mathrm{MW}$ has been considered as a reference scenario. The energy and exergy analyses of the existing plant were carried out to evaluate the actual performances in terms of total power output, efficiency, and specific $\mathrm{CO}_{2}$ emission. Afterward, the repowering of the existing plant was proposed by integrating the MCFC unit for $\mathrm{CO}_{2}$ capture downstream of the existing power plant. A partial reduction of the total natural gas input into the exiting combined-cycle plant was proposed to be used to run the integrated MCFC unit downstream of the existing plant. Finally, the energy and exergy analyses of the proposed repowered scheme have been carried out in Cycle Tempo software [25]. The performances of both the existing and the proposed repower plant have been compared from the energetic, exergetic, and environmental perspectives.

The rest of this paper is structured as follows. In Section 2, the plant configuration and modeling are explained. The thermodynamic energy modeling and basic assumptions are presented in Section 3, and the main results are discussed in Section 4. 


\section{Plant Configuration and Modeling}

In this study, the research efforts have been devoted to investigating the potential application of MCFC in natural gas-based power plants for carbon capture. The general arrangement layout for the reference existing natural gas turbine power plant located in Italy is reported in Figure 1. The original reference plant has one single gas turbine (GT) unit. The exhaust gases from the gas turbine have been equally divided into two similar three pressure level heat recovery steam generators (HRSG) connected with one reheatregenerative steam Rankine cycle each. In this theoretical model and analysis, for simplicity of plant design in the Cyclo Tempo software, one single HRSG, and one single steam cycle unit have been considered to achieve the same net total power output of the two steam cycles of the original existing plant. However, the plant orientation, as well as the operating and design conditions, remains the same for each steam cycle of the original plant.

The gas turbine unit consists of an air compressor (AC), a combustion chamber (CC), a gas turbine (GT), a generator (GEN), and a fuel preheater (FPH). Fresh air is compressed by the $\mathrm{AC}$ and sent to the $\mathrm{CC}$. After being preheated at the $\mathrm{FPH}$, the heated natural gas reaches the CC. After the combustion process, the hot flue gases expand through the GT and pass through the HRSG before going to the atmosphere through the STAC. The steam generated at the HRSG helps run the reheat-regenerative steam Rankine cycle with three pressure levels of steam expanding at the three different pressure level steam turbines, i.e., the high-pressure turbine (HPT), the intermediate pressure turbine (IPT), and the low-pressure turbine (LPT). The three turbines are coupled in a single shaft with the generator (GEN). After the expansion in the LPT, the steam is condensed at the condenser (COND) to yield saturated liquid water. A cooling water circulation pump (CWCP) circulates the water for steam condensation at the COND. The condensate pump (CP) then sends the liquid water to the deaerator (DEA) through the feedwater preheater (FWPH) section of the HRSG unit. A fraction of bleed steam is taken from the LPT and is sent to the DEA for the deaeration process. From the DEA the feed water is sent to the three different pressure level steam generation sections of the HRSG by three different feed pumps, i.e., the high-pressure feed pump (HPFP), the intermediate pressure feed pump (IPFP), and the low-pressure feed pump (LPFP). The HPFP sends the feed water through the high-pressure steam generation circuit of the HRSG, consisting of three high-pressure economizers (HPEC 1,2,3), a highpressure evaporator (HPEV), a high-pressure drum (HPD), and a high-pressure superheater (HPS). After the expansion in the HPT, the steam is reheated at the reheater $(\mathrm{RH})$ before entering the IPT. The IPFP sends the feed water through the intermediate pressure steam generation circuit of the HRSG, which consists of an intermediate pressure economizer (IPEC), an intermediate pressure evaporator (IPEV), an intermediate pressure drum (IPD), and an intermediate pressure superheater (IPS). Similarly, the LPFP sends the feed water through the low-pressure steam generation circuit of the HRSG, consisting of a low-pressure economizer (LPEC), a low-pressure evaporator (LPEV), a low-pressure drum (LPD), and a low-pressure superheater (LPS). The intermediate pressure steam after expansion in the IPT is mixed with the low-pressure steam generated in the low-pressure steam generation section of HRSG. Then, finally, the total low-pressure steam expands at the LPT.

The integration of an MCFC for carbon capture from the combined-cycle plant is reported in Figure 2. For the modified plant, the basic configuration of the existing combined cycle remains the same. The detailed descriptions of the old existing combined-cycle plant have been given in the earlier section. The exhaust gas coming out from the HRSG unit is sent to the MCFC for carbon capture. The flue gas from the HRSG has been preheated in the flue gas preheater (FGPH) up to the working temperature of the MCFC using the waste heat available in the cathode off-gas of the MCFC unit. 


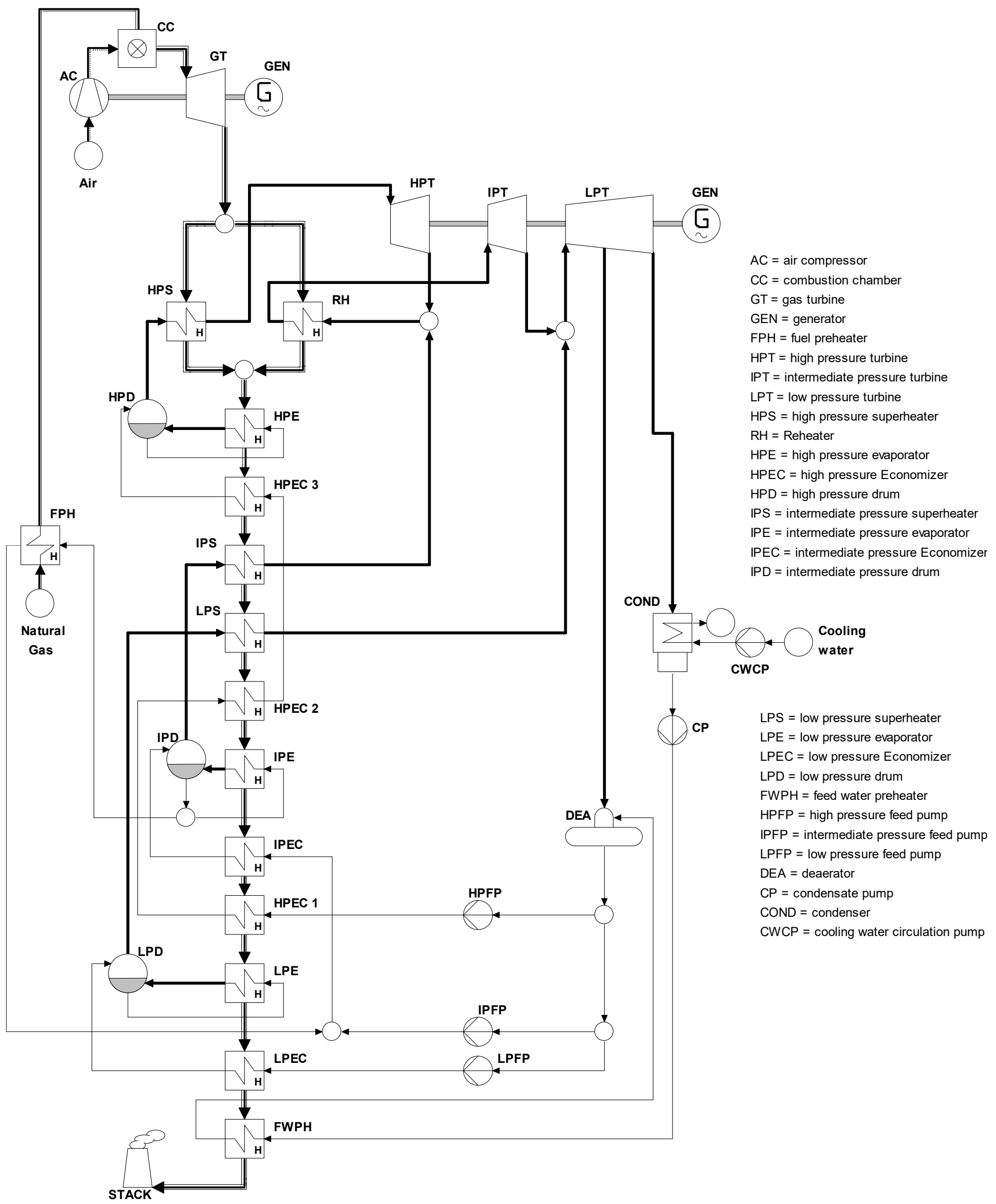

Figure 1. Existing natural gas-fired combined-cycle plant diagram in Cycle Tempo software interface. 


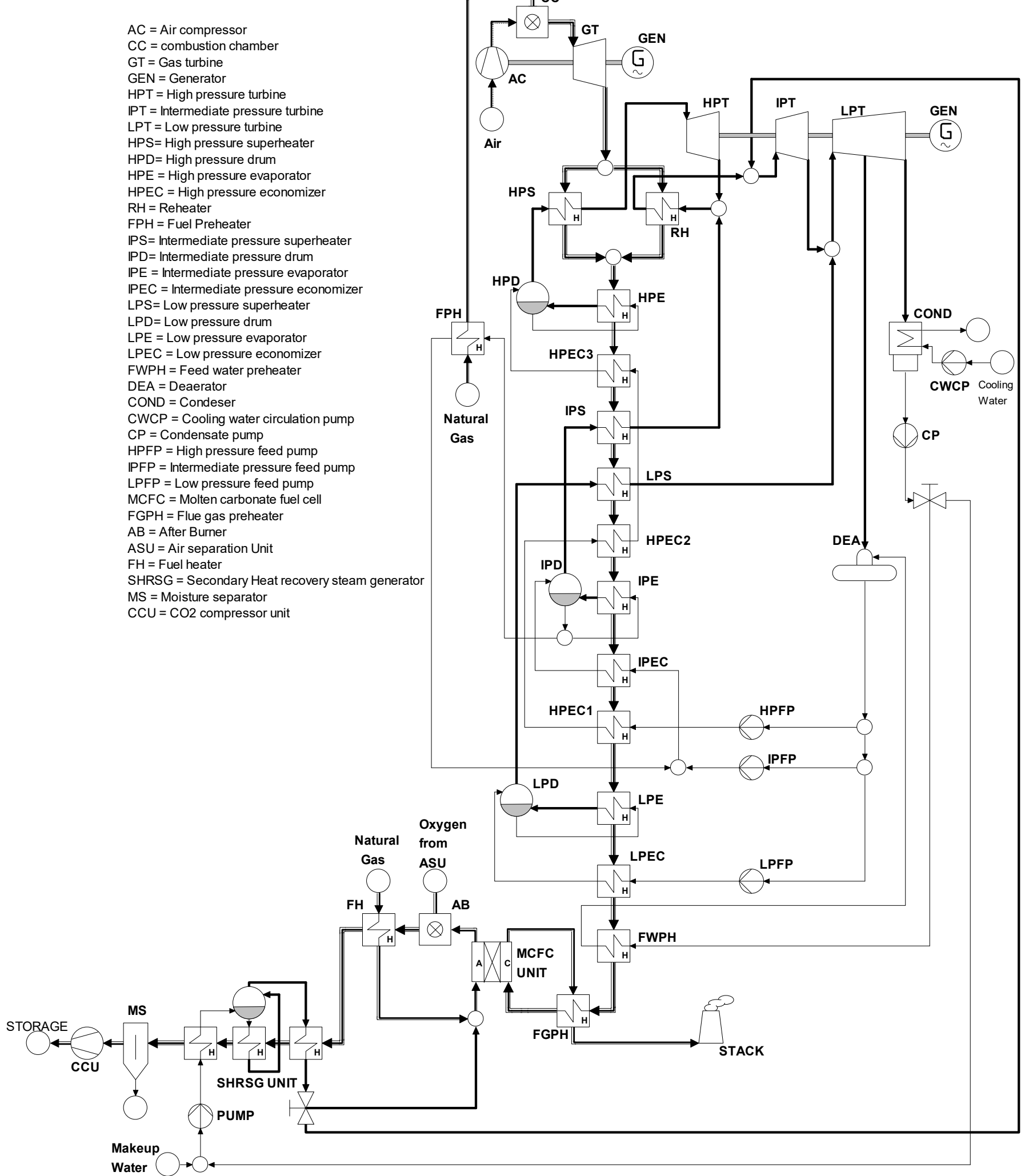

Figure 2. Proposed modified combined-cycle plant configuration in Cycle Tempo software interface.

The anode side of the MCFC is fed with natural gas mixed with steam. The amount of natural gas that has been discarded from supplying into the existing GT unit is supplied to the MCFC unit. Therefore, the total net fuel supply into the repower plant configuration remains the same as the old existing plant. Here, the MCFC stack is considered as an 
internally reforming type fuel cell unit. The residual fuel from the anode exhaust is burnt with the help of pure oxygen supplied from an air separation unit (ASU) followed by a fuel preheating at the fuel preheater (FH), a secondary heat recovery steam generation (SHRSG) unit, a moisture separation at the moisture separator (MS), and finally a $\mathrm{CO}_{2}$ compression and storage at 110 bar by the $\mathrm{CO}_{2}$ compression unit (CCU). The existing combined-cycle gas turbine plant configuration remains unaltered. The excess amount of steam, generated at the downstream SHRSG unit, is sent to the IPT of the existing combined-cycle plant, which helps in adding further power from the existing steam cycle. Some make water is supplied to the SHRSG to supply the amount of water consumed in the MCFC for the internal reforming process. The MCFC operates with high temperatures, usually above $600{ }^{\circ} \mathrm{C}$ to ensure electrolyte conductivity. Here, the cathode of the MCFC is fed with $\mathrm{CO}_{2}$ containing gas mixture, concentrating $\mathrm{CO}_{2}$ in the anode effluent. In the MCFC, the chemical energy of a fuel $\left(\mathrm{H}_{2} / \mathrm{H}_{2}\right.$-containing gas) is transformed into electrical energy through electrochemical reactions as shown in Figure 3.

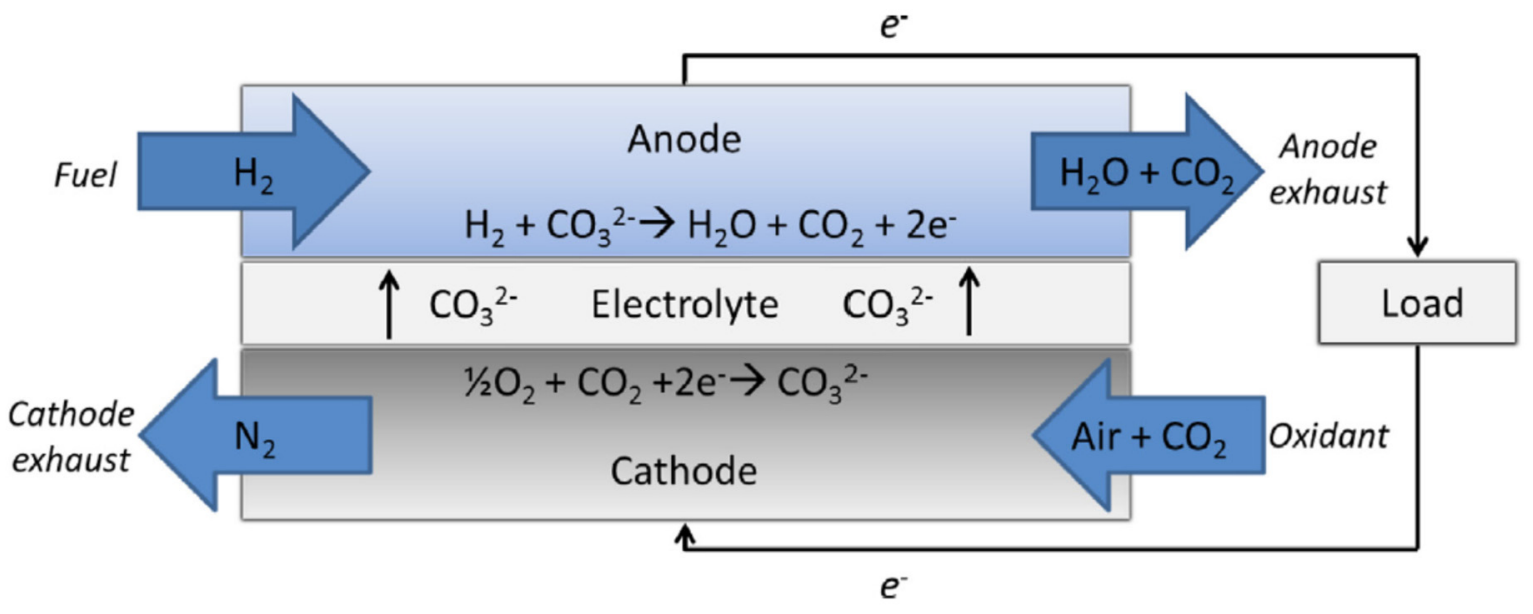

Figure 3. The basic working principle of an MCFC. Reprinted with permission from ref. [26], Copyright 2021 Rosaria Volpe.

At the anode channel, hydrogen is oxidized producing $\mathrm{CO}_{2}$ and water (Equation (1)), while at the cathode channel, oxygen is reduced by $\mathrm{CO}_{2}$ to produce carbonate ions (Equation (2)). The active charge carriers in the electrolyte are the generated carbonate ions; the MCFC has an intrinsic functionality of separating $\mathrm{CO}_{2}$ from the oxidant flow into the anode exhaust flow through the cell reaction (Equation (3)). Here, the MCFC is fed with the flue gas (containing $\mathrm{CO}_{2}$ ) in the cathode channel. On the other side, natural gas is supplied as fuel in the anode channel of the MCFC. Hydrogen is produced by steam reforming (Equation (4)) from the supplied natural gas. The carbon monoxide (CO) produced by the steam reforming is further converted into $\mathrm{H}_{2}$ and $\mathrm{CO}_{2}$ following water gas shift reaction (WGS) (Equation (5)).

$$
\begin{gathered}
\mathrm{H}_{2}+\mathrm{CO}_{3}^{-2} \rightarrow \mathrm{H}_{2} \mathrm{O}+\mathrm{CO}_{2}+2 \mathrm{e}^{-} \\
\frac{1}{2} \mathrm{O}_{2}+\mathrm{CO}_{2}+2 \mathrm{e}^{-} \rightarrow \mathrm{CO}_{3}^{-2} \\
\mathrm{H}_{2}+\frac{1}{2} \mathrm{O}_{2}+\mathrm{CO}_{2, \text { cathode }} \rightarrow \mathrm{H}_{2} \mathrm{O}+\mathrm{CO}_{2, \text { anode }} \\
\mathrm{CH}_{4}+\mathrm{H}_{2} \mathrm{O} \rightarrow \mathrm{H}_{2}+\mathrm{CO} \\
\mathrm{H}_{2} \mathrm{O}+\mathrm{CO} \rightarrow \mathrm{CO}_{2}+\mathrm{H}_{2}
\end{gathered}
$$

Here the MCFC anode side is fed with natural gas with steam which is internally reformed and generates the required $\mathrm{H}_{2}$ for the reaction at the anode. After the reaction, at the anode exhaust, there are $\mathrm{CO}_{2}, \mathrm{H}_{2} \mathrm{O}$, and residual fuel. This anode exhaust is proposed 
to be burnt in the afterburner (AB) with pure oxygen supplied from ASU. The aftercombustion gas contains only $\mathrm{CO}_{2}$ and $\mathrm{H}_{2} \mathrm{O}$. At the downstream of the $\mathrm{AB}$, the waste heat is proposed to be recovered by SHRSG, and $\mathrm{CO}_{2}$ is proposed to be captured after condensation of the moisture at the moisture separator (MS). At the cathode, the flue gas from the combined cycle is supplied. $\mathrm{CO}_{2}$ present in the boiler flue gas is transferred to the anode and residual gas goes to the stack as cathode exhaust. The downstream MCFC unit is operated as a power producer and $\mathrm{CO}_{2}$ separator for capture and sequestration at the same time.

\section{Thermodynamic Energy Modeling}

The existing power plant of Figure 1 and the proposed repowering scheme with MCFC of Figure 2 were modeled in the Cycle Tempo flow simulation software [25]. In the following, the assumptions chosen for the modeling of the two plants and the thermodynamic balance formulations are reported.

\subsection{Assumptions}

The modeling of the existing and retrofitted power plants is grounded on the following assumptions:

i. The isentropic efficiency values for the turbines, pumps, fans are considered as 88 , 86 , and $86 \%$, respectively, whereas the generator efficiency has been assumed to be $95 \%$ [13].

ii. The molar composition of the natural gas is taken as follows: $89 \% \mathrm{CH}_{4}, 7 \% \mathrm{C}_{2} \mathrm{H}_{6}, 1 \%$ $\mathrm{C}_{3} \mathrm{H}_{8}, 0.1 \% \mathrm{C}_{4} \mathrm{H}_{10}, 2 \% \mathrm{CO}_{2}, 0.89 \% \mathrm{~N}_{2}$, and the LHV is $46.502 \mathrm{MJ} / \mathrm{kg}$ [20].

iii. The fuel utilization factor is taken as $75 \%$ and the current density of MCFC is 1000 $\mathrm{A} / \mathrm{m}^{2}$. The cell voltage at the nominal condition is $0.7 \mathrm{~V}$, and the MCFC working temperature is set to $650{ }^{\circ} \mathrm{C}$ [20].

iv. Steam is added to achieve a steam to carbon ratio of 3.5 in the reforming charge [20].

v. The MCFC unit is isothermal; all the calculated chemical balances and the current density are based on the average cell temperature.

vi. The MCFC stack consists of several identical cells connected in series.

vii. The MCFC acts at near atmospheric pressure.

viii. All processes are analyzed to be steady.

ix. No pressure and heat losses are encountered in any of the state points and components.

x. Atmospheric pressure and temperature are assumed to be $1 \mathrm{~atm}$ and $25^{\circ} \mathrm{C}$, respectively.

\subsection{Thermodynamic Heat Balance}

The existing and repowered power plants have been simulated in Cycle Tempo flow simulation software [18]. Mass, energy, and heat balances of the power cycles have been derived considering each component as a control volume characterized by a uniform and steady flow.

The net power output, $P_{e x}$, of the existing plant is calculated as the difference between the gross power output and auxiliary power, as in Equation (6).

$$
P_{\text {net }, e x}=P_{\text {gross }, e x}-P_{\text {aux }, e x}
$$

Given the net power output of the plant, the net efficiency is obtained as:

$$
\eta_{e x}=\frac{P_{n e t, e x}}{m_{n g} \cdot L H V_{n g}} \times 100 \%
$$

Being $m_{n g}$ and $L H V_{n g}$ the mass and the lower heating value of natural gas, respectively. Concerning the operating characteristics of the MCFC, the cell voltage $V$ is given by:

$$
V=V_{0}-V_{N}-\Delta V
$$


In Equation (8), $V_{0}$ represents the maximum theoretically achievable reversible potential, $V_{N}$ the Nernst potential, and $\Delta V$ the voltage loss.

The Nernst voltage $V_{N}$, considered as the potential of an ideal fuel cell, has been derived from the work of Manzolini et al. [22] and expressed as:

$$
V_{N}=\frac{R T_{F C}}{2 F} \ln \left(\frac{p_{\mathrm{O}_{2, c t}}^{0.5} \times p_{\mathrm{H}_{2, a n}} \times p_{\mathrm{CO}_{2, c t}}}{O_{\mathrm{H}_{2} \mathrm{O}, a n} \times p_{\mathrm{CO}_{2, c t}}}\right)
$$

The Nernst voltage depends on the universal gas constant $R$ and the Faraday constant $F$, on the stack temperature of the fuel cell $T_{F C}$, and on the partial pressure $p$ of the chemical species of the fuel cell, for both the cathode $(c t)$ and the anode $(a n)$.

The Nernst voltage is associated with the Gibbs free energy deriving from the electrochemical reaction $\Delta G$, calculated as in Campanari et al. [20]:

$$
\Delta G=-242,000+45.8 \times T_{F C}
$$

From the change in the Gibbs energy of formation, the maximum theoretically achievable reversible potential $V_{0}$ can be calculated:

$$
V_{0}=-\frac{\Delta G}{2 F}
$$

Finally, the voltage loss $\Delta V$ is formulated by analogy with Ohm's law:

$$
\Delta V=i \times R_{t o t}
$$

where $i$ represents the current density and $R_{\text {tot }}$ is derived as the sum of the Ohomic loss $r_{\text {ohm }}$, the anodic and cathodic overpotential, $r_{a n}$ and $r_{c t}$, respectively, empirically obtained from Campanari et al. [20] for the operating temperature of the MCFC, and reported here below:

$$
\begin{gathered}
r_{\text {ohm }}=0.5 \times 10^{-4} \times e^{3016 \times\left(\frac{1}{T_{F C}}-\frac{1}{923}\right)} \\
r_{a n}=2.27 \times 10^{-9} \times e^{\frac{53,500}{R T}} \times p_{\mathrm{H}_{2}}^{-0.47} \times p_{\mathrm{CO}_{2}}^{-0.17} \times p_{\mathrm{H}_{2} \mathrm{O}}^{-1.0} \\
r_{c t}=7.505 \times 10^{-10} \times e^{\frac{77,229}{R T} T_{F C}} \times p_{\mathrm{O}_{2}}^{-0.43} \times p_{\mathrm{CO}_{2}}^{-0.09}
\end{gathered}
$$

The electrical output power of the MCFC can be calculated as:

$$
P_{\mathrm{MCFC}}=V \times i \times A \times \eta_{D C A C}
$$

where $A$ is the total area of the MCFC unit and $\eta_{D C A C}$ the conversion efficiency from DC to $A C$. The net rate of power output from the fuel cell is given as follows:

$$
P_{n e t, \mathrm{MCFC}}=P_{M C F C}-P_{a u x, \mathrm{MCFC}}
$$

Thus, the net power output from the repowering scheme is calculated as:

$$
P_{\text {net,repow }}=P_{\text {net,ex }}+P_{\text {net, } \mathrm{MCFC}}
$$

The total rate of heat input for the repowering scheme is reported below:

$$
Q_{\text {in,repow }}=m_{N G} \times L H V_{N G}
$$

with $m_{N G}$ and $L H V_{N G}$ being the mass and the lower heating value of natural gas, respectively.

The net efficiency of the repowering scheme can be calculated as in Equation (18):

$$
\eta_{\text {repow }}=\frac{P_{\text {net, repow }}}{Q_{\text {in, repow }}} \times 100 \%
$$


Concerning the environmental analysis, carbon emissions of the existing and repowered plants are derived from the output data of the simulations in Cycle Tempo. The specific $\mathrm{CO}_{2}$ emissions rate of the existing plant is formulated as:

$$
S_{\mathrm{CO}_{2}, e x}=\frac{m_{\mathrm{CO}_{2}, e x}}{P_{\text {net,ex }}}
$$

Being $m_{\mathrm{CO}_{2}, \text { ex }}$ the rate of $\mathrm{CO}_{2}$ emission from the existing plant:

$$
m_{\mathrm{CO}_{2} \text {, ex }}=\frac{m_{\text {flue gas }}}{M_{\text {flue gas }}} \times \xi_{\mathrm{CO}_{2}} \times M_{\mathrm{CO}_{2}}
$$

In Equation (20), $m$ and $M$ are the mass flow rate and the molecular weight of the corresponding gas, respectively; $\xi_{\mathrm{CO}_{2}}$ is the molar percentage of carbon dioxide. To estimate the rate of $\mathrm{CO}_{2}$ emissions from the repowering scheme, Equation (20) is applied to the cathode exhaust and anode burnout gas stream, as in:

$$
\begin{aligned}
m_{\mathrm{CO}_{2}} \text {, cathode exhaust } & =\frac{m_{\text {cathode exhaust }}}{M_{\text {cathode exhaust }} \times \xi_{\mathrm{CO}_{2}} \times M_{\mathrm{CO}_{2}}} \\
m_{\mathrm{CO}_{2} \text {, anode burnout gas }} & =\frac{m_{\text {anode burnout gas }}}{M_{\text {anode burnout gas }}} \times \xi_{\mathrm{CO}_{2}} \times M_{\mathrm{CO}_{2}}
\end{aligned}
$$

Therefore, the specific $\mathrm{CO}_{2}$ emissions rate from the repowering scheme is:

$$
S_{\mathrm{CO}_{2} \text {, repow }}=\frac{m_{\mathrm{CO}_{2} \text {, cathode exhaust }}+m_{\mathrm{CO}_{2} \text {, anode burnout gas }}}{P_{\text {net, repow }}}
$$

\subsection{Exergy Analysis}

The specific exergy, $e x$, associated with any stream can be split into two main components, e.g., the 'physical exergy', ex phy, and the 'chemical exergy', ex che.

$$
\begin{gathered}
e x=e x_{\text {phy }}+e x_{\text {che }} \\
e x_{\text {phy }}=\sum_{j} y_{j}\left(\left(\overline{h_{j}}-\overline{h_{0}}\right)-T_{0}\left(s_{j}-s_{0}\right)\right) \\
e x_{\text {che }}=\left(\sum_{J} y_{J} \overline{\bar{x}_{\text {che }}^{o}}+R T_{o} \sum_{j} y_{j} \ln y_{i}\right)
\end{gathered}
$$

The 'exergy destruction', $e x_{D}$, taking place in a component during a specific process can be evaluated as done in [26] and reported in Equation (26):

$$
E x_{D}=\sum_{k}\left(1-\frac{T_{o}}{T_{k}}\right) Q_{k}-W+\sum_{\text {in }} E x_{\text {in }}-\sum_{\text {out }} E x_{\text {out }}
$$

Being $T, Q, W$ the temperature, the heat transfer, and the work conducted, respectively. Exergy related to heat transfer is denoted by the first term on the right-hand side, $\sum_{k}\left(1-\frac{T_{o}}{T_{k}}\right) Q_{k}$. The second term $W$ represents the work carried out on the system, $\sum_{i n} E x_{i n}$ and $\sum_{\text {out }} E x_{\text {out }}$ the exergy associated with the incoming and outcoming stream, respectively. Exergy destruction for each component of the proposed system has been estimated as a function of the fuel exergy. It is calculated as follows:

$$
\begin{aligned}
x_{D} & =\frac{E x_{D}}{E x_{i n}} \\
x_{\text {Loss }} & =\frac{E x_{\text {Lost }}}{E x_{\text {in }}}
\end{aligned}
$$


'Fuel exergy' and 'product exergy' of each component are essential for estimation of the 'exergy efficiency' of that component. The fuel exergy gives indications on the resources consumed to produce the desired output; the product exergy corresponds to the desired outcome of the component. Therefore, the 'exergy efficiency' of a component can be expressed as a function of these two values, as estimated in [26].

$$
\phi_{\text {ex,comp }}=\frac{E x_{\text {product }}}{E x_{f u e l}}
$$

Overall, the system's exergy efficiency has been calculated as:

$$
\varphi_{\text {sys }}=1-\sum x_{D}-\sum x_{\text {Loss }}
$$

\section{Results and Discussion}

Energy and exergy analyses are grounded on the thermodynamic calculations of the previous Section and ensure a comprehensive performance evaluation of the existing and repowered combined-cycle power plant. The existing plant has been simulated in the cycle Tempo software and the major operating parameters are listed in Table 1 and compared with the data published in the reference study [4] for validation purposes. It can be observed from Table 1 that the Cycle Tempo model of the existing plant shows a good agreement with the values available from the original existing plant.

Table 1. Validation parameters for the simulated combined-cycle plant configuration.

\begin{tabular}{ccc}
\hline Parameters & Present Study & Reference Study [4] \\
\hline Airflow in Gas turbine Unit $(\mathrm{kg} / \mathrm{s})$ & 1299.97 & 1300 \\
\hline Fuel flow in Gas turbine Unit $(\mathrm{kg} / \mathrm{s})$ & 30.6 & 30.6 \\
\hline Gas flow at Gas turbine inlet $(\mathrm{kg} / \mathrm{s})$ & 1330.57 & 1330.6 \\
\hline Gas turbine inlet temperature $\left({ }^{\circ} \mathrm{C}\right)$ & 1268 & 1265.7 \\
\hline Gas turbine outlet temperature $\left({ }^{\circ} \mathrm{C}\right)$ & 608 & 608 \\
\hline HP steam flow rate $(\mathrm{kg} / \mathrm{s})$ & 152.89 & 153.7 \\
\hline HP steam pressure $(\mathrm{bar})$ & 121 & 120.9 \\
\hline HP steam temperature $(\mathrm{bar})$ & 559.5 & 559.5 \\
\hline IP steam flow rate $(\mathrm{kg} / \mathrm{s})$ & 183.48 & 185 \\
\hline IP steam pressure $(\mathrm{bar})$ & 23 & 22.96 \\
\hline IP steam temperature $(\mathrm{bar})$ & 561 & 561 \\
\hline Gas turbine unit output $(\mathrm{MW})$ & 544.39 & 292.78 \\
\hline Steam turbine unit output $(\mathrm{MW})$ & 291.05 & \\
\hline
\end{tabular}

The mass flow rate, pressure, and temperature of the existing combined-cycle plant depicted in Figure 1 are reported in Table 2. The net efficiency is around 58\% for the 829.797 MW power plant.

The proposed repowered system has around 787.454 MW of net power output. If compared with the existing plant configuration, the net energy efficiency and the exergy efficiency are reduced by less than $3 \%$. The $\mathrm{CO}_{2}$ emission factor significantly decreases, with almost 2 million tons of $\mathrm{CO}_{2}$ captured per year. The estimations of the exergy destruction for each component of the system are listed in Table 3. 
Table 2. Output performance parameters of the existing natural gas-fired combined-cycle plant.

\begin{tabular}{cc}
\hline Parameters & Values \\
\hline Gross power output (MW) & 833.438 \\
\hline Auxiliary power consumption (MW) & 3.461 \\
\hline Net Power Output (MW) & 829.797 \\
\hline Thermal input energy (MW) & 1422.9 \\
\hline Net Plant efficiency (\%) & 58.317 \\
\hline Net exergy efficiency (\%) & 56.212 \\
\hline Specific $\mathrm{CO}_{2}$ emission $(\mathrm{kg} / \mathrm{MWh})$ & 416.5 \\
\hline
\end{tabular}

Table 3. Output performance parameters of the modified combined-cycle plant with carbon capture and storage.

\begin{tabular}{cc}
\hline Parameters & Values \\
\hline Gas turbine output (MW) & 435.29 \\
\hline Steam cycle output (MW) & 248.9 \\
\hline Fuel cell output (MW) & 135.283 \\
\hline Auxiliary power consumption (MW) & 28.415 \\
\hline Power consumption by ASU (MW) & 3.604 \\
\hline Net Power Output (MW) & 787.454 \\
\hline Input energy in combined-cycle plant (MW) & 1138.32 \\
\hline Input energy in Fuel cell Unit (MW) & 284.58 \\
\hline Total input energy into the integrated plant (MW) & 1422.9 \\
\hline Net Plant efficiency (\%) & 55.34 \\
\hline Net exergy efficiency (\%) & 53.34 \\
\hline Specific $\mathrm{CO}_{2}$ emission (kg/MWh) & 66.67 \\
\hline Total annual CO 2 sequestrated (ton/year) & $1.991 \times 10^{6}$ \\
\hline
\end{tabular}

The exergy inputs of the existing natural-gas-fired combined-cycle power plants are reported in Figure 4. The amount of natural gas supplied to the retrofitted scheme is the same as the existing configuration; therefore, it can be assumed that the fuel exergy input does not vary in quantitative terms. In fact, for the repowered scheme, fuel is supplied for the operation of both the natural gas combined cycle and the MCFC. The useful exergy is around $56.21 \%$ of the total, with $40.87 \%$ of exergy destruction, and stack loss of almost $3 \%$. The highest amount of exergy destruction can be referred to as the combustion chamber (CC), due to the significant variation between the temperature reached during combustion and the temperature at the end of the heat transfer process to the fluid.

The details of the different contributions for the total exergy destruction are given in Figure 5. As can be observed, the highest contribution occurred in the combustion chamber (CC), with the destruction of around $28 \%$ of the total exergy. The gas turbine (GT), the air compressor (AC), and the heat recovery steam generator (HRSG) range around values of 2 to $4 \%$ of the total exergy destruction. The low-pressure turbine (LPT) is responsible for around $1 \%$, followed by lower values for the fuel preheater $(\mathrm{FPH})$, the high-pressure turbine (HPT), the intermediate pressure turbine (IPT), the condenser (COND), and the deaerator (DEA). 


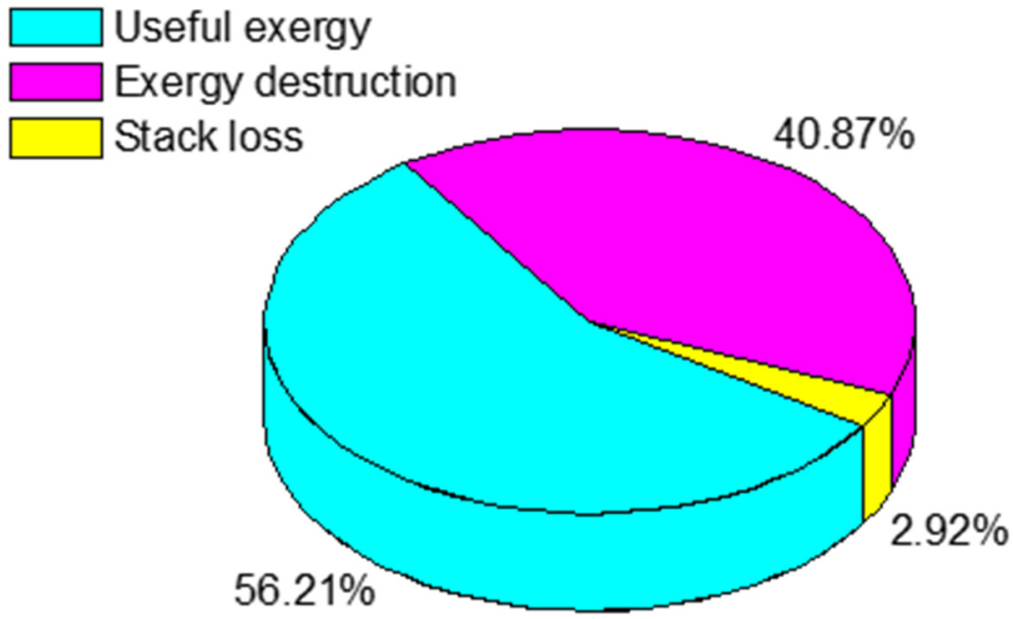

Figure 4. Distribution of total input exergy of the existing natural gas-fired combined-cycle plant.

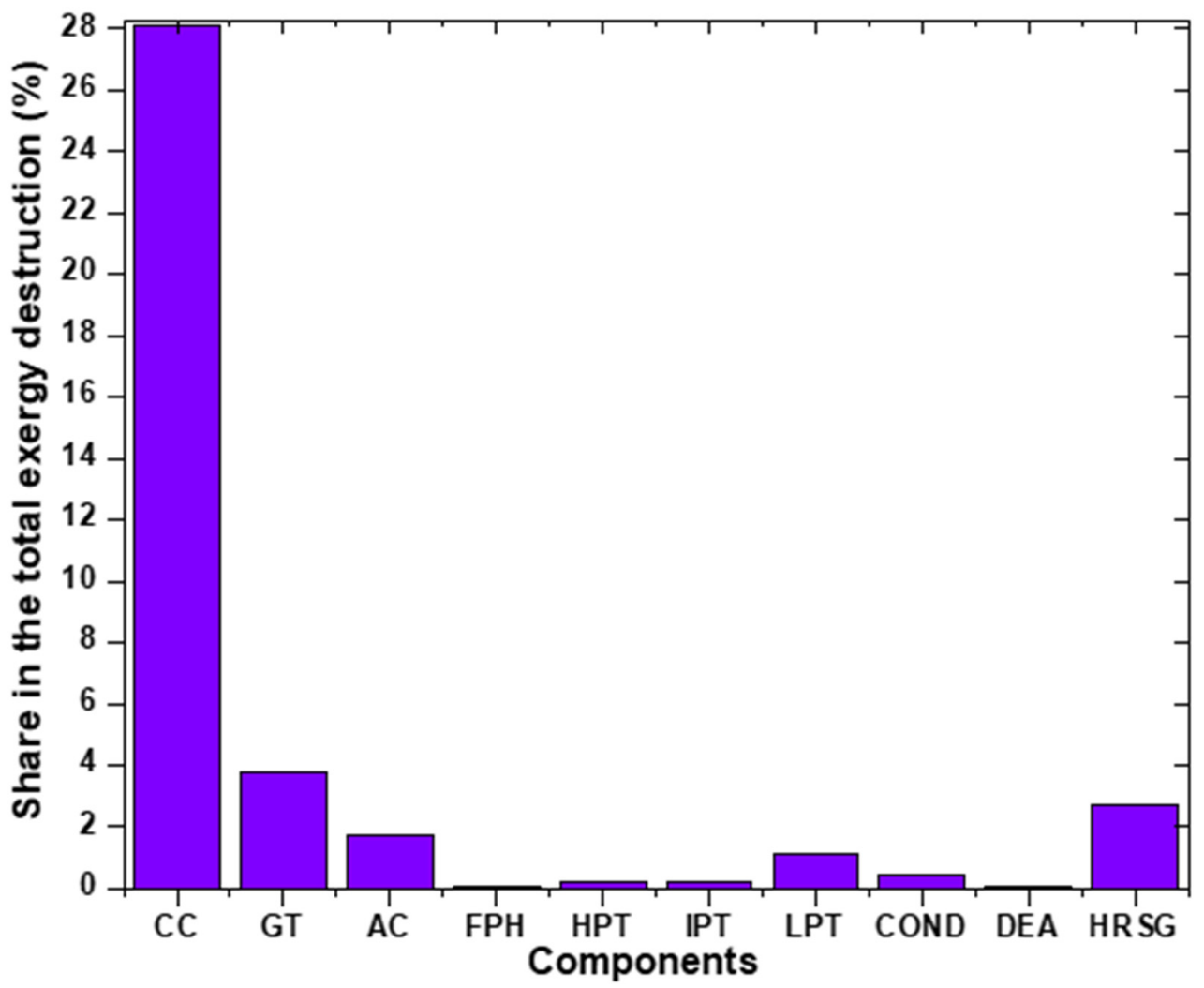

Figure 5. Components in total exergy destruction of the existing natural gas-fired combined-cycle power plant.

The exergy performances of the repowered scheme confirm the efficiency improvements that can be achieved by retrofitting the existing plant. They are summarized in the pie chart of Figure 6. As can be seen, the useful exergy here amounts to $53.34 \%$ of the total input exergy. Exergy due to the stack loss is reduced and the exergy loss related to the capture system is $3.22 \%$. The exergy destruction has been estimated to be around the $42.4 \%$, with the detail on the components reported in Figure 7. Here, similarly to the base case, the main contributions from the exergy destruction are due to the combustion process in the combustion chamber (CC). 
Useful exergy

Exergy destruction

Stack loss

$\square$ Exergy lost with captured CO2

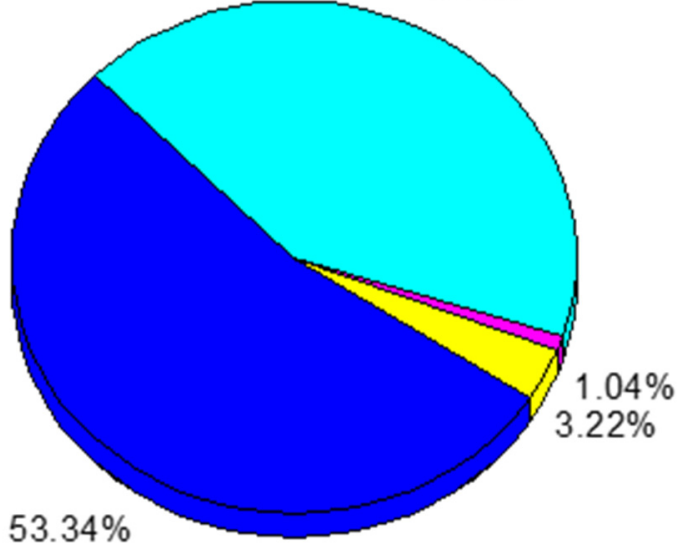

Figure 6. Distribution of total input exergy of the modified combined-cycle power plant with carbon capture.

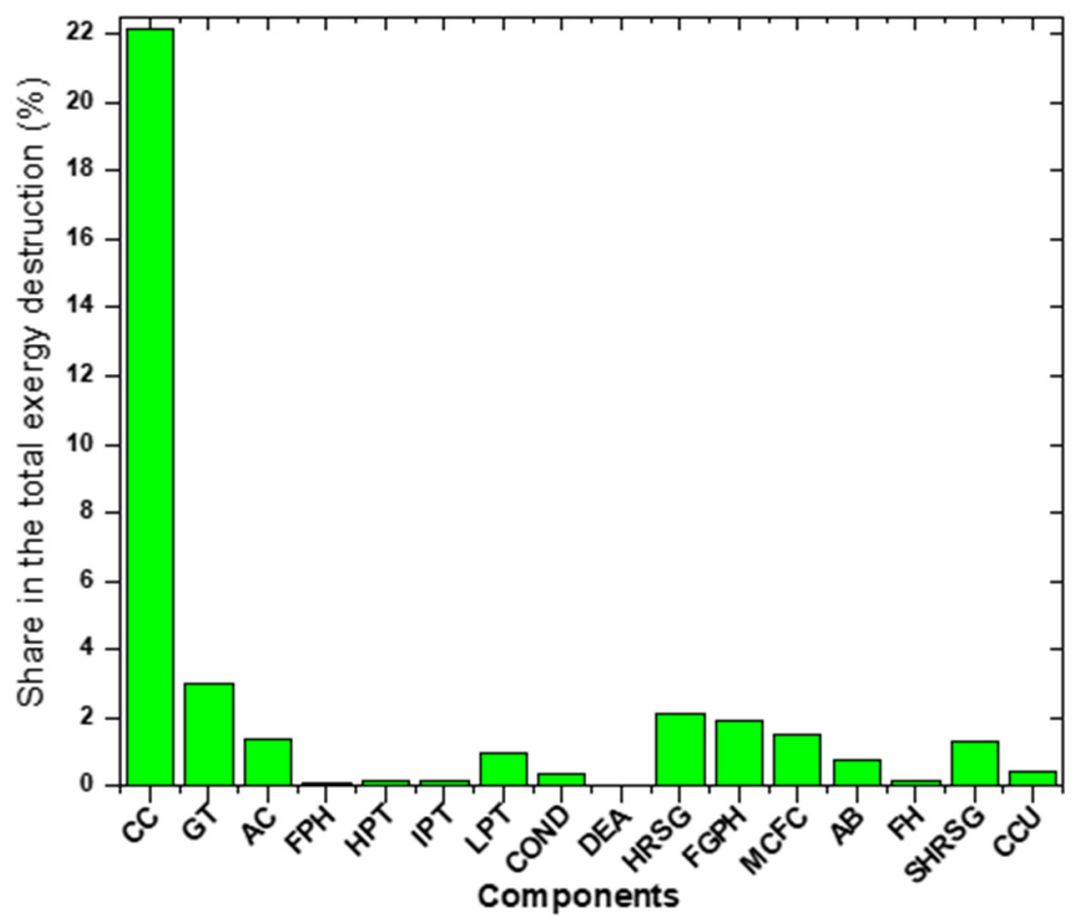

Figure 7. Components in total exergy destruction of the modified combined-cycle power plant with carbon capture.

Table 4 shows the amount of exergy destructed at the different major components of the existing combined-cycle plant and the modified repowered plant. As shown in Figures 5 and 7 that the CC, HRSG, GT, MCFC, SHRSG, etc. have the most significant contribution in total exergy destruction, a similar interpretation canbe seen from Table 4. 
Table 4. Amount of exergy destructed in major components of the existing plant and repowered plant.

\begin{tabular}{|c|c|c|c|c|}
\hline \multirow{2}{*}{ Sl.no. } & \multirow{2}{*}{$\begin{array}{l}\text { Name of the } \\
\text { Component }\end{array}$} & \multicolumn{2}{|c|}{ Amount of Exergy Destructed } & \multirow{2}{*}{ Unit } \\
\hline & & Existing Plant & Repowered Plant & \\
\hline 1 & $\mathrm{AC}$ & $25,622.66$ & $20,498.12$ & $\mathrm{~kW}$ \\
\hline 2 & $\mathrm{CC}$ & $418,049.22$ & $334,420.62$ & $\mathrm{~kW}$ \\
\hline 3 & GT & $56,355.88$ & $45,084.69$ & $\mathrm{~kW}$ \\
\hline 4 & $\mathrm{FPH}$ & 1257.12 & 1005.69 & $\mathrm{~kW}$ \\
\hline 5 & HRSG & $38,197.27$ & $30,575.74$ & $\mathrm{~kW}$ \\
\hline 6 & HPT & 3024.81 & 2419.43 & $\mathrm{~kW}$ \\
\hline 7 & IPT & 3334.95 & 2943.77 & $\mathrm{~kW}$ \\
\hline 8 & LPT & $16,344.15$ & $14,338.22$ & $\mathrm{~kW}$ \\
\hline 9 & COND & 6065.63 & 5224.94 & $\mathrm{~kW}$ \\
\hline 10 & CWCP & 229.18 & 203.47 & $\mathrm{~kW}$ \\
\hline 11 & $\mathrm{CP}$ & 12.21 & 10.90 & $\mathrm{~kW}$ \\
\hline 12 & DEA & 716.37 & 537.37 & $\mathrm{~kW}$ \\
\hline 13 & HPFP & 476.68 & 382.49 & $\mathrm{~kW}$ \\
\hline 14 & IPFP & 20.59 & 17.90 & $\mathrm{~kW}$ \\
\hline 15 & LPFP & 2.09 & 1.75 & $\mathrm{~kW}$ \\
\hline 16 & STACK & $43,439.18$ & $38,842.80$ & $\mathrm{~kW}$ \\
\hline 17 & FGPH & - & $28,721.55$ & $\mathrm{~kW}$ \\
\hline 18 & MCFC stack & - & $23,312.55$ & $\mathrm{~kW}$ \\
\hline 19 & $\mathrm{AB}$ & - & $11,441.98$ & $\mathrm{~kW}$ \\
\hline 20 & $\mathrm{FH}$ & - & 2804.30 & $\mathrm{~kW}$ \\
\hline 21 & SHRSG & - & $20,203.12$ & $\mathrm{~kW}$ \\
\hline 22 & PUMP & - & 14.98 & $\mathrm{~kW}$ \\
\hline 23 & MS & - & 5100.95 & $\mathrm{~kW}$ \\
\hline 24 & $\mathrm{CCU}$ & - & 4145.41 & $\mathrm{~kW}$ \\
\hline
\end{tabular}

\section{Conclusions}

In this work, thermodynamic analysis grounded on exergy estimation was conducted to evaluate the feasibility of retrofitting an existing natural-gas combined cycle with Molten Carbonate Fuel Cell to target the decarbonization needs of the power sector. An Italian reference power plant and the corresponding repowering scheme have been considered and simulated in Cycle Tempo software with specific underlying assumptions.

The proposed repowered power plant produces 787.454 MW, of which 435.29 MW refers to the gas turbine, $248.9 \mathrm{MW}$ to the steam cycle, and 135.283 MW to the MCFC. Overall exergy destruction of $42.4 \%$ has been obtained, the majority occurring in the combustion chamber (due to the significant variation between the temperature reached by combustion and the temperature achieved at the end of the heat transfer process to the fluid) and, in minor percentages, in the gas turbine and the MCFC. The net plant efficiency and net exergy efficiency are estimated to be around 55.34 and $53.34 \%$, respectively. Compared to the initial configuration, exergy due to the stack loss is reduced and the exergy loss related to the capture system is $3.22 \%$. Finally, the specific $\mathrm{CO}_{2}$ emission is around $66.67 \mathrm{~kg} / \mathrm{MWh}$ with around 2 million tons of carbon dioxide sequestrated. Future applications of this study may include the integration of renewable energy-based production systems. 


\begin{abstract}
Author Contributions: A.F.: Conceptualization, methodology, writing-original draft preparation, writing - review and editing, visualization, supervision, project administration, funding acquisition. S.S.: Conceptualization, methodology, software, validation, formal analysis, investigation, resources, data curation, writing - review and editing, visualization. R.V.: Conceptualization, methodology, writing — original draft preparation, writing—review and editing, visualization, supervision, project administration, funding acquisition. All authors have read and agreed to the published version of the manuscript.
\end{abstract}

Funding: This research was partially funded by the University of Catania in the framework of the SIS-RENEW research project (Piano di incentivi per la Ricerca 2020-2022).

Institutional Review Board Statement: Not applicable.

Informed Consent Statement: Not applicable.

Data Availability Statement: Not applicable.

Conflicts of Interest: The authors declare no conflict of interest.

\title{
References
}

1. United Nations, Department of Economics and Social Affairs, Population Division. World Urbanization Prospects; The 2018 Revision; United Nations: New York, NY, USA, 2019.

2. International Energy Agency (IEA). Global Energy Review 2021: Assessing the Effects of Economic Recoveries on Global Energy Demand and $\mathrm{CO}_{2}$ Emissions in 2021; International Energy Agency (IEA): Paris, France, 2021; Available online: https://iea.blob.core. windows.net/assets / d0031107-401d-4a2f-a48b-9eed19457335/GlobalEnergyReview2021.pdf (accessed on 1 October 2021).

3. United States Department of Energy. Annual Energy Outlook 2021 with Projections to 2050; U.S. Department of Energy: Washington, DC, USA, 2021.

4. Fernandez, E.S.; Goetheer, E.; Manzolini, G.; Macchi, E.; Rezvani, S.; Vlugt, T. Thermodynamic assessment of amine based $\mathrm{CO}_{2}$ capture technologies in power plants based on European Benchmarking Task Force methodology. Fuel 2014, 129, 318-329. [CrossRef]

5. Discepoli, G.; Cinti, G.; Desideri, U.; Penchini, D.; Proietti, S. Carbon capture with molten carbonate fuel cells: Experimental tests and fuel cell performance assessment. Int. J. Greenh. Gas Control. 2012, 9, 372-384. [CrossRef]

6. Gatti, M.; Martelli, E.; Di Bona, D.; Gabba, M.; Scaccabarozzi, R.; Spinelli, M.; Viganò, F.; Consonni, S. Preliminary Performance and Cost Evaluation of Four Alternative Technologies for Post-Combustion $\mathrm{CO}_{2}$ Capture in Natural Gas-Fired Power Plants. Energies 2020, 13, 543. [CrossRef]

7. Campanari, S.; Chiesa, P.; Manzolini, G.; Bedogni, S. Economic analysis of $\mathrm{CO}_{2}$ capture from natural gas combined cycles using Molten Carbonate Fuel Cells. Appl. Energy 2014, 130, 562-573. [CrossRef]

8. Mamaghani, A.H.; Najafi, B.; Shirazi, A.; Rinaldi, F. Exergetic, economic, and environmental evaluations and multi-objective optimization of a combined molten carbonate fuel cell-gas turbine system. Appl. Therm. Eng. 2015, 77, 1-11. [CrossRef]

9. Mahmoudi, S.; Ghavimi, A. Thermoeconomic analysis and multi objective optimization of a molten carbonate fuel cellSupercritical carbon dioxide-Organic Rankin cycle integrated power system using liquefied natural gas as heat sink. Appl. Therm. Eng. 2016, 107, 1219-1232. [CrossRef]

10. Mei, B.; Qin, Y.; Taghavi, M. Thermodynamic performance of a new hybrid system based on concentrating solar system, molten carbonate fuel cell and organic Rankine cycle with $\mathrm{CO}_{2}$ capturing analysis. Process. Saf. Environ. Prot. 2021, 146, 531-551. [CrossRef]

11. Akrami, E.; Ameri, M.; Rocco, M.V. Developing an Innovative biomass-based Power Plant for low-carbon Power production: Exergy and Exergoeconomic analyses. Therm. Sci. Eng. Prog. 2020, 19, 100662. [CrossRef]

12. Spallina, V.; Romano, M.C.; Campanari, S.; Lozza, G. Application of MCFC in Coal Gasification Plants for High Efficiency CO 2 Capture. J. Eng. Gas Turbines Power 2011, 134, 011701. [CrossRef]

13. Samanta, S.; Ghosh, S. A thermo-economic analysis of repowering of a $250 \mathrm{MW}$ coal fired power plant through integration of Molten Carbonate Fuel Cell with carbon capture. Int. J. Greenh. Gas Control. 2016, 51, 48-55. [CrossRef]

14. Li, M.; Zhuang, Y.; Song, M.; Li, W.; Du, J. Techno-economic and carbon footprint feasibility assessment for polygeneration process of carbon-capture coal-to-methanol/power and molten carbonate fuel cell. Energy Convers. Manag. 2021, $235,114015$. [CrossRef]

15. Spinelli, M.; Campanari, S.; Consonni, S.; Romano, M.C.; Kreutz, T.; Ghezel-Ayagh, H.; Jolly, S. Molten Carbonate Fuel Cells for Retrofitting Postcombustion $\mathrm{CO}_{2}$ Capture in Coal and Natural Gas Power Plants. J. Electrochem. Energy Convers. Storage 2018, 15, 031001. [CrossRef]

16. Slater, J.; Chronopoulos, T.; Panesar, R.; Fitzgerald, F.; Garcia, M. Review and techno-economic assessment of fuel cell technologies with $\mathrm{CO}_{2}$ capture. Int. J. Greenh. Gas Control. 2019, 91, 102818. [CrossRef]

17. Mehrpooya, M.; Sayyad, S.; Zonouz, M.J. Energy, exergy and sensitivity analyses of a hybrid combined cooling, heating and power (CCHP) plant with molten carbonate fuel cell (MCFC) and Stirling engine. J. Clean. Prod. 2017, 148, 283-294. [CrossRef] 
18. Ansarinasab, H.; Mehrpooya, M. Investigation of a combined molten carbonate fuel cell, gas turbine and Stirling engine combined cooling heating and power (CCHP) process by exergy cost sensitivity analysis. Energy Convers. Manag. 2018, 165, 291-303. [CrossRef]

19. Campanari, S.; Chiesa, P.; Manzolini, G.; Giannotti, A.; Federici, F.; Bedont, P.; Parodi, F. Application of $\mathrm{MCFC}$ for active CO 2 capture within natural gas combined cycles. Energy Procedia 2011, 4, 1235-1242. [CrossRef]

20. Campanari, S.; Chiesa, P.; Manzolini, G. $\mathrm{CO}_{2}$ capture from combined cycles integrated with Molten Carbonate Fuel Cells. Int. J. Greenh. Gas Control. 2010, 4, 441-451. [CrossRef]

21. Carapellucci, R.; Saia, R.; Giordano, L. Study of Gas-steam Combined Cycle Power Plants Integrated with MCFC for Carbon Dioxide Capture. Energy Procedia 2014, 45, 1155-1164. [CrossRef]

22. Manzolini, G.; Campanari, S.; Chiesa, P.; Giannotti, A.; Bedont, P.; Parodi, F. $\mathrm{CO}_{2}$ Separation from Combined Cycles Using Molten Carbonate Fuel Cells. J. Fuel Cell Sci. Technol. 2011, 9, 011018. [CrossRef]

23. Carapellucci, R.; Cipollone, R.; Di Battista, D. MCFC-Based System for Active $\mathrm{CO}_{2}$ Capture from Flue Gases. In ASME International Mechanical Engineering Congress and Exposition; Volume 6A: Energy; American Society of Mechanical Engineers: Pittsburgh, PA, USA, 2018.

24. Barelli, L.; Bidini, G.; Campanari, S.; Discepoli, G.; Spinelli, M. Performance assessment of natural gas and biogas fueled molten carbonate fuel cells in carbon capture configuration. J. Power Sources 2016, 320, 332-342. [CrossRef]

25. Cycle-Tempo Software Version 5; Asimptote: Heeswijk Dinther, The Netherlands; Available online: http://www.asimptote.nl/ software/cycle-tempo/ (accessed on 1 October 2021).

26. Rexed, I.; della Pietra, M.; McPhail, S.J.; Lindbergh, G.; Lagergren, C. Molten carbonate fuel cells for $\mathrm{CO}_{2}$ separation and segregation by retrofitting existing plants-An analysis of feasible operating windows and first experimental findings. Int. J. Greenh. Gas Control. 2015, 35, 120-130. [CrossRef] 